\title{
Market Share and Cash Policy: Evidence from Western European Companies
}

\author{
Frederiek Schoubben ${ }^{1,2} \&$ Cynthia Van Hulle ${ }^{2}$ \\ ${ }^{1}$ Department of Business Studies, Lessius University College, Antwerp, Belgium \\ ${ }^{2}$ Faculty of Business and Economics, University of Leuven (KU Leuven), Leuven, Belgium \\ Correspondence: Frederiek Schoubben, Lessius University College, Department of Business Studies, Korte \\ Nieuwstraat 33, 2000 Antwerpen, Belgium. Tel: 32-3-201-1831. E-mail: frederiek.schoubben@lessius.eu; KU \\ Leuven, Faculty of Business and Economics, Department of Accountancy, Finance and Insurance (Research \\ Centre Finance), Naamsestraat 69, 3000 Leuven, Belgium. E-mail: frederiek.schoubben@kuleuven.be
}

Received: September 7, $2012 \quad$ Accepted: September 19, $2012 \quad$ Online Published: September 28, 2012

doi:10.5539/ijef.v4n11p51 URL: http://dx.doi.org/10.5539/ijef.v4n11p51

The authors thank Nico Dewaelheyns (KU Leuven, Faculty of Business and Economics), Bert D'Espallier (University College Brussels, Department of Business Studies), Herbert Rijken (VU Amsterdam, Department of Finance and Financial Sector Management), Rosy Locorotondo (KU Leuven, Faculty of Business and Economics) and the participants of the 2011 WHU Campus for Finance Research Conference in Vallendar (Germany), for comments and suggestions on earlier versions of this paper.

\begin{abstract}
This study analyses the impact of market share on corporate cash policy in a static as well as a dynamic framework. Using a panel data set of large firms in 14 European countries, we show that firms with high market share tend to have lower cash holdings. This relationship between market share and cash policy is most apparent when predation risk, measured using either the similarity of a firm's technology with its industry rivals or market concentration, is high. These findings are robust for different estimation methods, different variables definitions, and for controlling for possible endogeneity between cash holdings and market share.
\end{abstract}

Keywords: competition, corporate finance, financing policy, market structure, cash holdings

JEL classification: D43, G31, G32, L11

\section{Introduction}

Recent studies show that corporations hold significant amounts of cash in Europe (Ferreira \& Vilela, 2004) as well as in the United States (Bates, Kahle, \& Stulz, 2009). The literature puts forward several motives that could explain the level of cash holdings. First, the transaction motive posits that firms can save on transaction costs by using cash reserves to make payments instead of having to liquidate assets. A second explanation for cash holdings by firms is based on the agency perspective. Managers have a preference for cash because it reduces firm risk and increases their discretion. Despite some empirical evidence supporting the transaction and agency motives for holding cash, the recent increase in cash holdings around the world has mostly been attributed to a hedging or precautionary motive (e.g., Bates et al., 2009). Firms tend to hedge against a possible shortfall of financial resources in the future by maintaining a cash buffer. Moreover, an important driver of these hedging needs has been shown to be an increase in industry competitiveness (e.g., Morellec \& Nikolov, 2008; Gaspar \& Massa, 2006). Since firms want to avoid underinvestment, increased competitive risk results in an increase in cash holdings for hedging purposes (Opler et al., 1999; Mikkelson \& Partch, 2003; Frésard, 2010). Elaborating on this latter issue, a recent strand of literature highlights the link between corporate cash holdings -as a hedging tool against competition- and product market dynamics. Research shows that firms tend to hold more cash when they are exposed to more intensive product market competition (Haushalter, Klasa, \& Maxwell, 2007; Morellec $\&$ Nikolov, 2008). Firms take into account the risk that rivals may prey on them, which in turn leads to a positive relationship between cash balances and predation risk within an industry. Next to this impact of product market dynamics on optimal cash levels, it has also been shown that cash policy itself can significantly influence competitive outcomes. Frésard (2010) for example, shows that cash rich firms outperform their more financially 
fragile rivals. Although the empirical evidence supports the notion that holding cash is beneficial for the firm, the implications of this hedging motive for the design of a firms' cash policy is much less understood.

Preceding studies do not take into account that the competitive pressure that a firm is subjected to, depends upon its position in its industry, i.e. its market share. In this study, we evaluate how the predation risk in an industry can influence the relationship between a firm's market share and its cash policy. To test this, we examine the cash holdings of large European firms from 14 countries over the 1998 to 2008 period in a static as well as a dynamic framework. Our sample has the advantage that extensive yearly financial statement information is available for listed as well as non listed firms, so that competitive measures can be calculated on a yearly basis including these non listed firms (Note 1). We find that corporate cash holdings are related to market share and predatory risk. Specifically, our results show that a firm is more likely to hold cash reserves when its market share is low. Furthermore, we find that the association between market share and cash holdings is most important when the risk of predation is high. This predatory risk can be proxied using firm specific measures, as the interdependence of firms' investment opportunities with rivals, or industry specific measures, as market concentration. Our results hold after controlling for profitability, size, growth, leverage and several other cash determinants, and after controlling for possible endogeneity between cash holdings and the explanatory variables.

Our study contributes to the literature is three distinct ways. First, by focusing on the impact of a firm's market share on its cash policy, we explore a new direction in the causal relationship between product market behavior and financing policy. The findings of Frésard (2010) that cash rich firms are able to increase market share at the cost of their rivals, lead to the expectation that market share itself should play an important role in a firm's optimal cash policy. Although previous studies have identified a significant impact of the market position of a firm on its capital structure decisions (e.g., Kovenock \& Phillips, 1997; MacKay \& Phillips, 2005; Campello, 2006), the impact on cash holdings is far less understood. Second, by showing that market share does in fact not only influence cash policy but that this influence depends upon the competitive environment (i.e., predatory risk), this study contributes to our understanding of the cash-competition dynamics. Similarly, our study also complements the work of Akdogu and Mackay (2008) who establish a link between the predatory risk caused by industry competitiveness and strategic investment behavior. Finally, this paper adds to studies like Haushalter et al. (2007) by showing that firms not only take into account the competitive intensity of their industry or the similarity of their technology but also their competitive position relative to rivals within this industry (i.e., market share), when they select their optimal cash position.

The next section provides a brief review of prior literature on the determinants of corporate cash holdings as well as an overview of prior findings on the relationship between product market competition and corporate liquidity. Section 3 outlines the empirical methodology. Section 4 describes the data while Section 5 presents and discusses the findings. The final section concludes.

\section{Literature Review and Hypotheses}

\subsection{Cash Policy Motives}

One of the classical explanations in corporate finance why firms build up liquidities, is the transaction motive. Firms retain a certain level of cash holdings in order to avoid transaction costs associated with converting a noncash financial asset into liquidities when cash outlays arise. Firms are expected to hold more cash when the cost of raising extra financing is higher (Baumol, 1952). A second motive for cash policy is related to agency costs. As argued by Jensen (1986), entrenched managers would rather retain cash than increase payouts to shareholders when the firm has poor investment opportunities (Dittmar, Mahrt-Smith, \& Servaes, 2003; Pinkowitz, Stulz, \& Williamson, 2006; Dittmar \& Marht-Smith, 2007).

However, since the seminal work of Opler et al. (1999), many papers show the importance of a precautionary build up of cash reserves to hedge against underinvestment (Almeida, Campello, \& Weisbach, 2004; Han \& Qui, 2007; Bates et al., 2009; among others). A quickly growing body of research shows that important drivers of precautionary cash holdings include income uncertainty due to riskier cash flows (Riddick \& Whited, 2009), financing constraints due to poor access to external capital (Han \& Qui, 2007; Pal \& Ferrando, 2010) or higher financing costs due to informational asymmetries between investors and managers (Almeida et al., 2004). This strand of research also suggests that firms with better investment opportunities hold more cash because adverse shocks and financial distress are more costly for them (Opler et al., 1999). Finally, Acharya, Almeida, and Campello (2007) develop a model showing that firms accumulate cash instead of reducing debt when the risk of an income shortfall is high due to low correlation between operating income and investment opportunities. 


\subsection{Interaction between Cash Policy, Market Share and Product Market Competition}

A recent debate that has emerged from the general cash literature, concerns the relation between cash policy and product market competition. Based primarily on the hedging logic of the precautionary motive, several studies look at the impact of the competitive environment on corporate cash policy. Haushalter et al. (2007) for example, study the influence of product market dynamics on cash policy. They argue that, when deciding on their optimal amount of cash, firms take into account the risk of losing investment opportunities to rivals. Haushalter et al. (2007) show that this predation risk is positively associated with the level of cash holdings. Using similar arguments, Morellec and Nikolov (2008) suggest that the recent findings of Bates et al. (2009) that US firms hold more cash than they used to, can be partly attributed to a rise in industry competitiveness over the last decade. In a similar vein, Gaspar and Massa (2006) investigate the link between the competitive environment and stock market performance, and attribute the rise in idiosyncratic volatility of stocks to the increase in industry competitiveness. Consistent with the relation between cash holdings and income uncertainty induced by increasing product market competition, Frésard (2010) provides evidence that a cash buffer protects firms against predator behavior of competitors while allowing them to better survive exogenous shocks in the product market. Finally, Bolton and Scharfstein (1990) argue that the ability to finance investments with internally generated funds is a key to success in the product markets.

Although cash holdings offer firms protection against predation by rivals as well as the opportunity to prey upon rivals themselves, preceding evidence raises the question whether firms that have a large market share should be less concerned about predation and therefore reduce their cash savings. The hedging logic from the literature discussed above suggests that this would indeed be the case in an equilibrium setting. Hay and Liu (1997) show that within an industry, market share increases with firm efficiency. The theoretical foundation of the hypothesis that market dominance is driven by higher efficiency that generates greater profitability can be found in the industrial organization literature (e.g., Demsetz, 1974; Schmalensee, 1989). As a result, firms with an important market share are less likely to invite predation, as forcing an efficient competitor out of the market is likely to be excessively costly. Furthermore, Bolton and Scharfstein (1990) argue that rivals prey more aggressively on more vulnerable firms. In sum, because they are better placed to fend off predatory attacks, the more dominant firms in an industry should be less concerned about inducing predation than the non-dominant firms. This leads to our main hypothesis:

Hypothesis 1: Firms with higher market share hold less cash.

If market share is helpful in shielding a firm from predation, it should have more impact on cash holdings in industries where predation risk is high. For in such a situation, firms experience a need to hedge against this risk by increasing cash holdings. However if a firm can better shield itself against predators as its market share increases, its need for more cash holdings diminishes, ceteris paribus. Froot, Scharfstein, and Stein (1993) and Haushalter et al. (2007) argue that a firm's exposure to predation risk depends on the interdependence of its investment opportunities with product market rivals. This leads to our second testable hypothesis:

Hypothesis 2: The relationship between market share and cash holdings is stronger when interdependence of investment opportunities between rivals is high

Next to the interdependence of investment opportunities, also industry characteristics can influence rival to rival behavior. Haushalter et al. (2007) argue that as market concentration increases within an industry, predation risk increases. Supporting this notion, Akdogu and MacKay (2008) show that competition forces firms to invest more quickly as competitors may take away the investment option. However, Akdogu and MacKay (2008) also show that strategic corporate investment aimed at deterrence, pre-emption, or predation is highest in oligopolistic industries. In perfectly competitive markets, predator behavior is unlikely to be effective because prices are equal to marginal costs and there is no gain from destroying one rival in a market with many players. In monopolistic markets, predator behavior is unlikely to happen because of collusion. Therefore, if market share shields a company from predation risk, its impact on cash policy should be most important in moderately concentrated industries where predation risk is substantial (Kovenock \& Phillips, 1997; Zingales, 1998). Preceding arguments suggest our final hypothesis:

Hypothesis 3: The relationship between market share and cash holdings is stronger in moderately concentrated industries as compared to industries where concentration is either very low or very high.

\section{Empirical Framework}

We test our hypotheses concerning the impact of market share on cash holdings in a static as well as a dynamic framework using panel data. The panel data setting makes it possible to test the role of the cash policy 
determinants while controlling for firm specific heterogeneity. It also enables to elaborate the static framework and determine whether changes in the firms' cash ratios follow a partial adjustment model. This dynamic setting assumes that firms pursue a target level when making their cash holdings decision. This way, the levels of cash at any time are also explained by the decisions taken in previous periods. As discussed below, this approach has therefore the additional advantage that we can control for possible reverse causality between cash holdings and the explanatory variables.

\subsection{Traditional Determinants of Cash Holdings}

In the static framework, we estimate fixed effect models of the relationship between cash holdings and market share. Similarly to other studies like Ozkan and Ozkan (2004) and Garcia-Teruel and Martınez-Solano (2008), our measure of cash holdings (CASH) is calculated as the ratio of cash and marketable securities to total assets (Note 2). The control variables in our cash models are similar to those in previous empirical studies. These determinants and their expected influence on cash holdings are briefly summarized below. An overview of all variable definitions can be found in Table 1 .

Growth (GROWTH) is expected to positively affect cash levels (Opler et al., 1999; Ferreira \& Vilela, 2004; Ozkan \& Ozkan, 2004). Firms with more investment opportunities are likely to keep higher liquidity levels in order to limit the probability of cash shortfalls, which could jeopardize their profitable investment projects. In this study we measure growth opportunities (GROWTH) as the median industry sales growth in a particular year based on a triple digit industry classification (i.e., SIC codes).

Size (SIZE) is often found to affect cash holdings due to the economies of scale that larger firms can realize in the cash levels required to finance day-to-day operations (Opler et al., 1999). Therefore, we expect a negative relation between firm size, measured as the natural logarithm of total assets, and cash holdings.

Leverage (LEV) likely also affects a firm's cash holdings. Empirical evidence (Opler et al., 1999; Ferreira \& Vilela, 2004; Ozkan \& Ozkan, 2004) suggests a negative relationship between financial leverage and cash. The argument is that leverage and cash can be considered substitutes since firms can always issue debt when cash shortfalls occur. However, both Ozkan and Ozkan (2004) and Ferreira and Vilela (2004) argue that the predicted relationship between leverage and cash is ambiguous. Since high debt levels increase the probability of financial distress, high levered firms could also increase cash holdings to counter this risk. They find, however, no evidence for the positive relationship between leverage and cash holdings. Leverage is defined as the ratio of total debt to total assets.

Cash flow (CF) is also a determinant of a firm's cash holdings. Due to the hierarchy of financing sources (Myers \& Majluf, 1984), firms with large cash flows are expected to keep higher cash levels, as is confirmed by Opler et al. (1999) and Ozkan and Ozkan (2004) for the US and British markets respectively, or by Ferreira and Vilela (2004), for European Monetary Union countries. We define cash flow (CF) as the ratio of EBITDA over total assets in our empirical analysis.

Other liquid assets (LIQ), apart from cash and marketable securities, are expected to reduce cash holdings, since these assets can be considered substitutes for cash. In line with Garcia-Teruel and Martınez-Solano (2008), we define other liquid assets (LIQ) as net working capital minus cash and marketable securities divided by total assets.

Cash flow uncertainty (RISK) increases the probability of cash shortfalls, ceteris paribus (Opler et al., 1999). Hence, risky firms should increase cash holdings in order to avoid cash shortfalls. We measure RISK as the standard deviation of the cash flow ratio defined above over the last three years. 
Table 1. Definitions of variables

\begin{tabular}{|c|c|}
\hline Variable names & Definitions \\
\hline \multicolumn{2}{|l|}{ Dependent variable } \\
\hline Cash holdings (CASH) & Cash + Marketable securities/ Total assets \\
\hline \multicolumn{2}{|l|}{ Explanatory variables } \\
\hline Growth opportunities (GROWTH) & $\left(\right.$ Ind.Sales $_{t}-$ Ind.Sales $\left._{t-1}\right) /$ Ind.Sales $_{t-1}$ \\
\hline Size (SIZE) & $\operatorname{Ln}$ (Total assets) \\
\hline Leverage (LEV) & Total debt/ Total assets \\
\hline Cash flow (CF) & Ebitda/ Total assets \\
\hline Other liquid assets (LIQ) & (Net working capital - (Cash + Marketable securities))/ Total assets \\
\hline Cash flow volatility (RISK) & Standard deviation of the cash flow ratio (CF) over the last three years \\
\hline Market share (MSHARE1) & Company sales divided by total sales in 3 digit SIC code industry \\
\hline Market schare (MSHARE2) & Company sales divided by total sales in 4 digit SIC code industry \\
\hline
\end{tabular}

\subsection{Market Share and Predation Risk}

In line with Gaspar and Massa (2006), we estimate market share (MSHARE1) as the annual sales of the firm divided by total industry sales. In order to proxy the total sales of the industry in a given year, we add up the sales of all firms with the relevant industry specification code. This gives us a time variant measure of the market share for a particular firm relative to its industry. The selection of the relevant industry specification deserves further attention. In line with Morellec and Nikolov (2008), we base our industry specification on industry codes. More specifically, we include all firms with consolidated financial statements of 14 European countries in our data set. We define industries on the basis of 3-digit European-wide SIC codes. All firms with the same industry codes are considered likely competitors. By using consolidated statements to calculate market share we reduce the risk of double counting sales due to pyramidal ownership structures. By incorporating several European countries, we also avoid possible biases by measuring market share at the country level. Especially the large firms in our dataset can be expected to compete far beyond country borders. As a robustness check however, we will also use alternative proxies of market share either by changing the industry classification to 4-digit SIC codes (MSHARE2) or by defining industries on the country level.

In order to differentiate firms and industries based on predatory risk, we use either interdependence of a firm's investment opportunities with rivals, or market concentration. Following Mackay and Phillips (2005), we proxy this interdependence by measuring the similarity of the technology used by a firm with that of its rivals. This similarity measure is the absolute value of the difference between a firm's ratio of net plant and equipment per employee and the median ratio in its industry. Analogue to Haushalter et al. (2007), we scale the absolute difference with the standard deviation of all capital-to-labor ratios in a particular industry, in order to make the similarity measure comparable across industries. Firms with smaller values of this similarity measure will be faced with higher predation risk because their technology, and thus also their investment opportunities, are more similar to rivals. In contrast to Haushalter et al. (2007), the similarity measure is not used as a continuous variable for predation risk in the cash models. As we wish to estimate the impact of predation risk on the relationship between market share and cash holdings, subsamples of firms that are very similar to their rivals (i.e., high predation risk) are compared to subsamples of firms with low similarity, based on the median value of the similarity measure.

A potential problem with the similarity measure in a multi-country empirical setting, is that it could be biased due to possible institutional differences in the capital-to-labor ratio (Dew-Becker \& Gordon, 2008). Therefore, our alternative country corrected measure for similarity uses the absolute value of the residuals of an auxiliary regression where the firm specific capital-to-labor ratio is the dependent variable explained by the industry median value of this ratio and country fixed effects. The country corrected similarity measure represents the scaled distance between a firm's observed and forecasted ratio of capital-to-labor. The basis of the forecast is the company's industry while controlling for country specific effects. Again, smaller values of this measure indicate a greater similarity of a firm's technology with industry rivals and therefore more interdependence of investment opportunities.

As a second proxy for predation risk, we measure market concentration based on the same industry classification (3-digit SIC codes) used in the market share variable. Following Gaspar and Massa (2006) and Hou and Robinson (2006), market concentration is measured by the Herfindahl Hirschman Index (HHI), which is the sum 
of squared market shares over all companies in an industry in a particular year. As in Haushalter et al. (2007), we expect predation risk to be higher when industry concentration increases. However, in the most concentrated (i.e., monopolistic) industries, the predation risk should drop as the probability of collusion increases (Kovenock \& Phillips, 1997; Zingales, 1998; Akdogu \& Mackay, 2008). For this reason we divide the total sample in three groups of market concentration based on the $33^{\text {rd }}$ and $67^{\text {th }}$ percentiles of the HHI variable thus creating a middle group (mid HHI) of moderately concentrated (i.e., oligopolistic) industries between low concentrated (low HHI) and highly concentrated markets (high HHI). Using the arguments leading up to our hypothesis 3 , we expect the predation risk in this middle group of moderately concentrated industries to be the highest.

\subsection{The Static and Dynamic Estimation Model of Cash Holdings}

The static cash model frequently used in previous research implicitly assumes that firms can instantaneously adjust towards the target cash level following changes in firm-specific characteristics and/or random shocks. The dynamic framework allows for an adjustment process involving a lag in the adjustment to changes in the target cash structure (Ozkan \& Ozkan, 2004). In fact, by adding a lagged cash ratio in the model, we turn the static model into a dynamic one. Hence, when we include the lagged cash ratio we estimate the following dynamic panel data specification:

$$
\begin{gathered}
\mathrm{CASH}_{i t}=\alpha+\delta_{0} \mathrm{CASH}_{i t-1}+\delta_{1} \text { GROWTH }_{i t}+\delta_{2} \mathrm{SIZE}_{i t}+\delta_{3} \mathrm{LEV}_{i t}+\delta_{4} C F_{i t}+\delta_{5} L I Q_{i t}+\delta_{6} R I S K_{i t}+ \\
\delta_{7} \text { MSHARE }_{i t}+\eta_{i}+\lambda_{t}+\varepsilon_{i t}
\end{gathered}
$$

where $\eta_{i}$ and $\lambda_{t}$ represent firm-specific effects and time-effects respectively. It is assumed that firm-specific effects are unobservable but have a significant impact on cash holdings. They differ across firms but are fixed for a given firm through time. In contrast, time-effects vary through time but are the same for all firms in a given year, capturing mainly economy-wide factors that are outside the firms' control. The inclusion of the lagged cash variable has important consequences for the estimation methodology. Models can no longer be tested with fixed effect OLS estimation due to correlation between the lagged cash level and the time invariant firm specific effect. The coefficient of the lagged cash variable $\delta_{0}$ can be interpreted as an inverse measure of the adjustment speed. A firm's ability to reach the target level of cash holdings in a certain year can be represented by $\left(1-\delta_{0}\right)$. If $\delta_{0}$ equals 0 , the speed of adjustment equals 1 and the firm adjusts instantaneously towards the optimal cash target level. A low speed of adjustment (i.e., $\delta_{0}$ reaching 1 ) would indicate that modification of the cash level is very costly (see e.g., Ozkan and Ozkan (2004) and Garcia-Teruel and Martinez-Solano (2008), for an elaborate discussion of the properties of the partial adjustment model of cash holdings).

We estimate the dynamic cash model by applying GMM according to the Arellano and Bond (1991) method. The technique consists of taking the first differences of the model and then applying the generalized method of moments (GMM) using the lagged levels of the endogenous variables as instrumental variables. Taking first differences also controls for the non observable fixed firm effect $\left(\eta_{i}\right)$. The consistency of estimates is obviously subject to an optimal choice of instruments where the validity of instruments depends on the absence of higher-order serial correlation in the idiosyncratic component of the error term. Therefore, a test for the second-order serial correlation is performed. We also apply the Sargan test of over-identifying restrictions to test whether the instruments and residuals are independent.

\section{Data Collection and Descriptive Statistics}

For our empirical investigation we use an unbalanced sample of non-financial listed as well as unlisted European companies from 14 countries over the period 1998-2008. We include all firms with consolidated financial statements available in the Amadeus Database of Bureau Van Dijk. Bureau Van Dijk standardizes balance sheet information with the objective of achieving cross-border uniformity. Even after the enlargement of the European Union the 14 EU countries in our sample (i.e., Belgium, Germany, Denmark, Spain, Finland, France, UK, Ireland, Italy, Netherlands, Portugal, Sweden) represent about $90 \%$ of total EU GDP (based on Eurostat statistics for 2010). Norway and Switzerland are included because of their major trade relationship with the European Union with import and export representing between $75 \%$ and $70 \%$ of their trade volume respectively (based on Eurostat statistics for 2010). Some countries from the pre enlargement members (e.g., Luxembourg, Greece and Austria) are not included due to the lack of consolidated statements in the Amadeus database.

The data set consists of 126509 available firm year observations corresponding to 22239 firms. Due to the extensive use of lagged values both in the variable definitions and estimation methodology, the effective sample in the reported univariate and multivariate results is somewhat smaller. To minimize the influence of outliers in the analysis, we replace extreme observations of all ratio variables with missing values. Extreme observations include values in the $99^{\text {th }}$ percentile and, for variables with negative values, also those in the $1^{\text {st }}$ percentile. 
In order to characterize the firms of the sample, we report the descriptive statistics of the variables used in Table 2. The summary statistics for the cash variable are similar to other studies using European data in the same time period. Companies are holding roughly $10 \%$ of their assets in cash or cash equivalents. Growth opportunities measured as the industry sales growth is around $5 \%$. The average company in our data set has total assets of about 40 million euro. Firms are on average highly leveraged, with total debt to total assets (LEV) amounting to $63 \%$. The cash flow variable (CF) and other liquid assets (LIQ) are very similar to the statistics in other empirical studies. The EBITDA of our firms amounts to $11 \%$ of total assets on average while they hold about $16 \%$ of total assets in net working capital other than cash. The average cash flow uncertainty of $4 \%$ is relatively high compared to the average cash flow measure. Finally, our main measure of market share MSHARE1) varies between a minimum of virtually 0 to a maximum of almost 1 . However, our average firm does not dominate the market as it owns $1 \%$ of the (3 digit) industry sales. This increases to $2 \%$ on average when we reduce the industry size by adopting the more detailed 4-digit SIC code (MSHARE2) as industry classification. These low average market shares are not surprising in view of the large number of firms - listed as well as unlisted - that we consider to be rivals in our relatively broad industry classifications.

Table 2. Summary statistics

\begin{tabular}{llllll}
\hline Variable & Mean & Median & Minimum & Maximum & Std. dev. \\
\hline CASH & 0.10 & 0.06 & 0.00 & 0.50 & 0.10 \\
GROWTH & 0.05 & 0.06 & -0.40 & 0.78 & 0.06 \\
SIZE & 10.58 & 10.50 & 2.77 & 19.44 & 2.12 \\
LEV & 0.63 & 0.65 & 0.00 & 1.00 & 0.20 \\
CF & 0.11 & 0.10 & -0.98 & 0.99 & 0.10 \\
LIQ & 0.16 & 0.16 & -0.99 & 0.99 & 0.25 \\
MSHARE1 & 0.01 & 0.00 & 0.00 & 1.00 & 0.06 \\
MSHARE2 & 0.02 & 0.00 & 0.00 & 1.00 & 0.09 \\
RISK & 0.04 & 0.03 & 0.00 & 0.99 & 0.05 \\
\hline
\end{tabular}

\section{Empirical Findings}

\subsection{Market Share and Cash Holdings}

Table 3 reports the results from the static fixed effect models as well as the dynamic GMM models of cash holdings (Note 3). We first assess the relevance of the dynamic framework by checking the GMM models with the lagged dependent variable $\mathrm{CASH}_{\mathrm{t}-1}$. The Sargan test of over-identifying restrictions as well as the direct tests of serial correlation in the residuals never rejects the validity of the lagged values of endogenous regressors as instruments. The significantly positive coefficients for the lagged cash variable amounting to 0.180 in both GMM model estimations correspond to a speed of adjustment of $82 \%$. Consistent with other findings in the literature for large firms (e.g., Guney et al., 2003; Ozkan \& Ozkan, 2004; among others) this result suggests that our sample companies pursue a target level of cash holdings that balances the costs and benefits of keeping cash while maintaining a high adjustment speed. For the remainder, the findings for the static and dynamic models are quite similar.

The static fixed effects models as well as the dynamic GMM models of Table 3 show a significant negative impact of market share, both MSHARE1 and MSHARE2, on cash holdings. In line with our first hypothesis concerning hedging against predation risk, higher market share leads to lower cash holdings. This result suggests that one of the advantages of having a higher market share is that one can afford to keep lower cash holdings and hence reduce the opportunity costs associated with maintaining a cash buffer. It is also consistent with earlier findings of Frésard (2010) that indicate that market share is an important determinant of corporate policy.

For the remainder, the models in Table 3 show that the other determinants of cash holdings are mostly significant with the expected sign. Larger and highly levered firms tend to hold less cash while cash flow generation leads to an increase in cash holdings. When alternative sources of liquidity are abundant however, firms lower their cash reserves. By contrast, risky firms increase their cash buffer in order to reduce the chances of a possible cash shortage in low income years. The only determinant that does not follow the expectations is growth opportunities. Better growth opportunities should increase cash holdings but the variable GROWTH is never significant (Note 4). 


\subsection{Industry Dynamics and Predation Risk}

If hedging against predation risk is an important driver of the relationship between market share and cash holdings, the impact of market share on cash policy should increase when predation risk mounts. In order to test this, we re-estimate our cash models in subsamples based on firm-specific (i.e., similarity) as well as industry-specific (i.e., market concentration) proxies for predation risk.

Table 3. The impact of market share in static and dynamic cash models

\begin{tabular}{|c|c|c|c|c|}
\hline \multirow[b]{2}{*}{$\begin{array}{l}\text { Explanatory var } \\
\text { (expected sign) }\end{array}$} & Fixed effects & GMM & Fixed effects & GMM \\
\hline & (1) & (2) & (3) & (4) \\
\hline \multirow[t]{2}{*}{ Intercept } & $0.247 * * *$ & & $0.248 * * *$ & \\
\hline & (28.02) & & (28.08) & \\
\hline \multirow[t]{2}{*}{$\mathrm{CASH}_{\mathrm{t}-1}$} & & $0.179 * * *$ & & $0.180 * * *$ \\
\hline & & (20.37) & & $(20.28)$ \\
\hline \multirow[t]{2}{*}{ GROWTH } & 0.003 & 0.004 & 0.004 & 0.004 \\
\hline & $(0.48)$ & $(1.24)$ & $(0.77)$ & $(1.26)$ \\
\hline \multirow[t]{2}{*}{ SIZE $\quad(-)$} & $-0.011 * * *$ & $-0.006^{* * *}$ & $-0.011 * * *$ & $-0.006 * * *$ \\
\hline & $(-13.39)$ & $(-7.56)$ & $(-13.46)$ & $(-7.48)$ \\
\hline \multirow[t]{2}{*}{ LEV $\quad(+/-)$} & $-0.035^{* * *}$ & $-0.035^{* * *}$ & $-0.035 * * *$ & $-0.034 * * *$ \\
\hline & $(-13.37)$ & $(-12.28)$ & $(-13.46)$ & $(-12.26)$ \\
\hline \multirow[t]{2}{*}{$\mathrm{CF} \quad(+)$} & $0.017 * * *$ & $0.089^{* * *}$ & $0.017 * * *$ & $0.089 * * *$ \\
\hline & (3.89) & $(28.90)$ & (3.88) & (28.93) \\
\hline \multirow[t]{2}{*}{ LIQ (-) } & $-0.089 * * *$ & $-0.422 * * *$ & $-0.089 * * *$ & $-0.422 * * *$ \\
\hline & $(-35.42)$ & $(-181.86)$ & $(-35.21)$ & $(-181.81)$ \\
\hline \multirow[t]{2}{*}{ RISK $\quad(+)$} & $0.036 * * *$ & $0.011^{* * *}$ & $0.036^{* * *}$ & $0.011 * * *$ \\
\hline & $(5.20)$ & $(4.15)$ & $(5.21)$ & $(4.15)$ \\
\hline \multirow[t]{2}{*}{ MSHARE1 } & $-0.014 *$ & $-0.013^{*}$ & & \\
\hline & $(-1.82)$ & $(-1.88)$ & & \\
\hline \multirow[t]{2}{*}{ MSHARE2 } & & & $-0.011^{*}$ & $-0.015^{*}$ \\
\hline & & & $(-1.67)$ & $(-1.88)$ \\
\hline Obs. & 98,586 & 79,166 & 98,586 & 79,166 \\
\hline Adjusted $\mathrm{R}^{2}$ & 0.6948 & & 0.6949 & \\
\hline Sargan & & n.s. & & n.s. \\
\hline $\mathrm{m} 1$ & & $* * *$ & & $* * *$ \\
\hline $\mathrm{m} 2$ & & n.s. & & n.s. \\
\hline
\end{tabular}

This table reports the results for the static (i.e., Fixed effects) as well as the dynamic (i.e., GMM) cash models (White's heteroskedasticity consistent $\mathrm{t}$-statistics in parentheses). The dependent variable in all models is the CASH variable measured as cash and cash equivalents divided by total assets. The Sargan test is $\chi^{2}$ distributed, its significance is reported in the Table. Level of significance: ***1\%; **5\%; *10\%; n.s. indicates non significance.

\subsubsection{Firm Specific Proxies for Predation Risk}

Tables 4 and 5 report the results of the static and the dynamic cash models respectively, estimated on subsamples based on interdependence of investment opportunities between rivals. Using either the similarity of technology measure analogue to Haushalter et al. (2007) or a country corrected similarity measure, we divide the full sample in subsamples of firms with technologies that are similar to their industry rivals or not. For, as argued in Haushalter et al. (2007), firms with similar technologies (i.e., investment opportunities) face higher predation risk. In the first two models of Table 4, subsamples are formed based on the median value of the main similarity measure, while the two models on the right hand side of the table compare the most and least similar firms according to the country corrected similarity measure (Note 5).

In line with our second hypothesis, the impact of market share changes as a function of the interdependence of investment opportunities (i.e., similarity of technology) with rivals. When rivals use a similar technology, predation risk likely is higher, which in turn leads to an increased importance of market share. This result holds 
for both similarity measures in Table 4 . When firms are less similar to rivals, market share seems to have no significant influence on the level of cash holdings. This result also relates to Mackay and Phillips (2005) who show that financing decisions depend not only on firm specific characteristics but also on the firm's position within its industry. For the remainder, Table 4 shows that the control variables in the static models do not differ much between the similarity subsamples, suggesting that subdividing according to interdependence of investment opportunities has little impact on the relationship of other determinants with cash holdings.

Table 4. The impact of market share depending on firm specific proxies for predation risk in a static model

\begin{tabular}{|c|c|c|c|c|}
\hline \multirow[b]{2}{*}{$\begin{array}{l}\text { Explanatory var } \\
\text { (expected sign) }\end{array}$} & \multicolumn{2}{|l|}{ Similarity } & \multicolumn{2}{|c|}{ Country corrected similarity } \\
\hline & (similar) & (not similar) & (similar) & (not similar) \\
\hline \multirow[t]{2}{*}{ Intercept } & $0.220 * * *$ & $0.254 * * *$ & $0.245^{* * *}$ & $0.228 * * *$ \\
\hline & $(15.28)$ & $(19.31)$ & $(17.22)$ & $(16.43)$ \\
\hline \multirow[t]{2}{*}{ GROWTH } & 0.005 & 0.004 & 0.002 & -0.004 \\
\hline & $(0.52)$ & $(0.66)$ & $(0.23)$ & $(-0.47)$ \\
\hline \multirow[t]{2}{*}{ SIZE $\quad(-)$} & $-0.008 * * *$ & $-0.013 * * *$ & $-0.011 * * *$ & $-0.010 * * *$ \\
\hline & $(-6.03)$ & $(-10.14)$ & $(-8.47)$ & $(-7.32)$ \\
\hline \multirow[t]{2}{*}{ LEV $\quad(+/-)$} & $-0.038 * * *$ & $-0.026 * * *$ & $-0.037 * * *$ & $-0.037 * * *$ \\
\hline & $(-9.00)$ & $(-6.92)$ & $(-8.39)$ & $(-7.92)$ \\
\hline \multirow[t]{2}{*}{$\mathrm{CF} \quad(+)$} & $0.010^{* *}$ & $0.018 * * *$ & $0.051 * * *$ & $0.040 * * *$ \\
\hline & $(2.02)$ & $(3.14)$ & $(7.92)$ & $(6.79)$ \\
\hline \multirow[t]{2}{*}{ LIQ $\quad(-)$} & $-0.083 * * *$ & $-0.094 * * *$ & $-0.095 * * *$ & $-0.067 * * *$ \\
\hline & $(-21.40)$ & $(-23.95)$ & $(-23.12)$ & $(-16.62)$ \\
\hline \multirow[t]{2}{*}{ RISK $\quad(+)$} & $0.036^{* * *}$ & $0.021 *$ & 0.017 & $0.034 * * *$ \\
\hline & $(3.01)$ & $(1.98)$ & $(1.49)$ & $(3.15)$ \\
\hline \multirow[t]{2}{*}{ MSHARE1 } & $-0.050 * * *$ & 0.001 & $-0.037 * * *$ & 0.028 \\
\hline & $(-3.07)$ & $(0.07)$ & $(-3.91)$ & $(1.60)$ \\
\hline Obs. & 44,410 & 44,937 & 44,254 & 44,031 \\
\hline Adjusted $\mathrm{R}^{2}$ & 0.7059 & 0.7106 & 0.7079 & 0.7001 \\
\hline
\end{tabular}

This table reports the results for the static (i.e., Fixed effects) cash models (White's heteroskedasticity consistent t-statistics in parentheses) tested on subsamples of firms that are either using similar technologies compared with rivals or not. The dependent variable in all models is the CASH variable measured as cash and cash equivalents divided by total assets. Level of significance: ***1\%; ** $5 \%$; *10\%.

Table 5, which estimates the dynamic models on the same subsamples as those of Table 4, shows similar results. Again, and in line with our second hypothesis, market share influences cash policy only for firms that face higher predation risk. For both similarity measures, the coefficient estimate for market share is significantly negative only when the interdependence of investment opportunities is high. As in Table 4, the coefficients of the other control variables vary little between subsamples. 
Table 5. The impact of market share depending on firm specific proxies for predation risk in a dynamic model

\begin{tabular}{|c|c|c|c|c|}
\hline \multirow[b]{2}{*}{$\begin{array}{l}\text { Explanatory var } \\
\text { (expected sign) }\end{array}$} & \multicolumn{2}{|l|}{ Similarity } & \multicolumn{2}{|c|}{ Country corrected similarity } \\
\hline & (similar) & (not similar) & (similar) & (not similar) \\
\hline \multirow{2}{*}{$\mathrm{CASH}_{\mathrm{t}-1}$} & $0.133 * * *$ & $0.151 * * *$ & $0.153 * * *$ & $0.127 * * *$ \\
\hline & (11.56) & (13.23) & (12.12) & (12.07) \\
\hline \multirow[t]{2}{*}{ GROWTH } & 0.005 & 0.005 & 0.002 & 0.004 \\
\hline & $(0.82)$ & $(1.29)$ & $(0.49)$ & $(0.88)$ \\
\hline \multirow[t]{2}{*}{ SIZE $\quad(-)$} & $-0.003^{* * *}$ & $-0.005 * * *$ & $-0.002 * *$ & $-0.007 * * *$ \\
\hline & $(-3.00)$ & $(-4.52)$ & $(-1.98)$ & $(-5.89)$ \\
\hline \multirow{2}{*}{ LEV $\quad(+/-)$} & $-0.051 * * *$ & $-0.028 * * *$ & $-0.035 * * *$ & $-0.042 * * *$ \\
\hline & $(-12.30)$ & $(-7.64)$ & $(-9.16)$ & $(-10.68)$ \\
\hline \multirow[t]{2}{*}{$\mathrm{CF} \quad(+)$} & $0.074 * * *$ & $0.083 * * *$ & $0.074 * * *$ & $0.083^{* * *}$ \\
\hline & $(16.50)$ & (18.59) & (16.19) & (19.54) \\
\hline \multirow{2}{*}{ LIQ $\quad(-)$} & $-0.398^{* * *}$ & $-0.417 * * *$ & $-0.405^{* * *}$ & $-0.406^{* * *}$ \\
\hline & $(-127.30)$ & $(-127.52)$ & $(-126.50)$ & $(-127.46)$ \\
\hline \multirow[t]{2}{*}{ RISK $\quad(+)$} & $0.007 * * *$ & $0.011 * * *$ & 0.004 & $0.010 * * *$ \\
\hline & $(3.00)$ & $(3.19)$ & $(0.84)$ & $(4.11)$ \\
\hline \multirow[t]{2}{*}{ MSHARE1 } & $-0.030^{*}$ & -0.009 & $-0.030 * * *$ & 0.011 \\
\hline & $(-1.82)$ & $(-1.09)$ & $(-3.10)$ & $(0.88)$ \\
\hline Obs. & 34,774 & 35,442 & 34,853 & 34,680 \\
\hline Sargan & n.s. & n.s. & n.s. & n.s. \\
\hline $\mathrm{m} 1$ & $* * *$ & $* * *$ & $* * *$ & $* * *$ \\
\hline $\mathrm{m} 2$ & n.s. & n.s. & n.s. & n.s. \\
\hline
\end{tabular}

This table reports the results for the dynamic (i.e., GMM) cash models (White's heteroskedasticity consistent t-statistics in parentheses) tested on subsamples of firms that are either using similar technologies compared with rivals or not. The dependent variable in all models is the CASH variable measured as cash and cash equivalents divided by total assets. Models are tested with GMM, estimated in first differences using the Arellano and Bond (1991) method. The validity of using lagged values of endogenous regressors as instruments was evaluated with the Sargan test of over-identifying restrictions and direct tests of serial correlation in the residuals $\mathrm{m} 1$ and $\mathrm{m} 2$. The Sargan test is $\chi^{2}$ distributed, its significance is reported in the Table. Level of significance: $* * * 1 \% ; * * 5 \% ; * 10 \%$; n.s. indicates non significance.

\subsubsection{Industry Specific Proxies for Predation Risk}

By separating firms in our sample on the basis of similarity between rivals, we implicitly assume that predatory risk only depends on the interdependence of investment opportunities, regardless of industry characteristics. However, Kovenock and Phillips (1997) and Zingales (1998) show that strategic behavior (e.g., predation) is more likely to occur in oligopolistic industries.

In order to test whether the relationship between market share and cash holdings differs between low concentrated, oligopolistic and monopolistic markets, we introduce market concentration as an industry specific proxy of predation risk. Analogue to Akdogu and Mackay (2008), we subdivide our sample in three groups based on our measure of market concentration (HHI) and using the $33^{\text {rd }}$ and $66^{\text {th }}$ percentile respectively (Note 6). We re-estimate the static as well as the dynamic cash models in the low, middle and high market concentration subsample. Hypothesis 3 predicts that as predation risk from product market competition is highest in the middle group (i.e., oligopolistic competition), the impact of market share should be more important in this group. Table 6 reports the results for these tests. In line with our hypothesis, the coefficient estimate of the market share variable (MSHARE1) is only significantly negative in the middle segment of market concentration. This implies that firms counter the threat of having a low market share with a cash buffer, only when strategic actions against rivals likely are effective. As argued above, when market concentration becomes very low or very high, the threat of predation decreases and hence also the importance of market share for cash policy. The coefficients of the other control variables are qualitatively similar between subsamples, indicating that the impact of the other cash determinants is not strongly influenced by industry dynamics.

In sum, our results support the notion that characteristics of the competitive environment influence the relationship between market share and cash policy. When predation risk increases, hedging through 
precautionary cash holdings becomes more important. In that kind of environment, market share becomes a significant determinant of cash policy as it reduces the risk of being preyed on.

Table 6. The impact of market share depending on industry specific proxies for predation risk

\begin{tabular}{|c|c|c|c|c|c|c|}
\hline \multirow[b]{2}{*}{$\begin{array}{l}\text { Explanatory variables } \\
\text { (expected sign) }\end{array}$} & \multicolumn{3}{|c|}{ Fixed effects } & \multicolumn{3}{|l|}{ GMM } \\
\hline & (low HHI) & (mid HHI) & (high HHI) & (low HHI) & (mid HHI) & (high $\mathrm{HHI}$ ) \\
\hline \multirow[t]{2}{*}{ Intercept } & $0.230 * * *$ & $0.261 * * *$ & $0.245 * * *$ & & & \\
\hline & $(14.18)$ & $(16.28)$ & (14.59) & & & \\
\hline \multirow{2}{*}{$\mathrm{CASH}_{\mathrm{t}-1}$} & & & & $0.192 * * *$ & $0.158 * * *$ & $0.186^{* * *}$ \\
\hline & & & & $(11.27)$ & $(11.62)$ & $(10.76)$ \\
\hline \multirow[t]{2}{*}{ GROWTH } & -0.023 & -0.011 & 0.001 & 0.004 & 0.001 & -0.005 \\
\hline & $(-1.74)$ & $(-0.82)$ & $(0.10)$ & $(0.47)$ & $(0.21)$ & $(-0.84)$ \\
\hline \multirow[t]{2}{*}{ SIZE $\quad(-)$} & $-0.011 * * *$ & $-0.012 * * *$ & $-0.011 * * *$ & $-0.006 * * *$ & $-0.007 * * *$ & $-0.006 * * *$ \\
\hline & $(-6.95)$ & $(-8.02)$ & $(-7.08)$ & $(-2.70)$ & $(-5.16)$ & $(-3.37)$ \\
\hline \multirow{2}{*}{ LEV $\quad(+/-)$} & $-0.030 * * *$ & $-0.035^{* * *}$ & $-0.031 * * *$ & $-0.050 * * *$ & $-0.045^{* * *}$ & $-0.022 * * *$ \\
\hline & $(-5.65)$ & $(-6.98)$ & $(-7.24)$ & $(-7.14)$ & $(-9.70)$ & $(-4.01)$ \\
\hline \multirow[t]{2}{*}{$\mathrm{CF} \quad(+)$} & $0.037 * * *$ & $0.010 * *$ & $0.008 * *$ & $0.083 * * *$ & $0.079 * * *$ & $0.086^{* * *}$ \\
\hline & $(6.45)$ & (1.99) & $(1.95)$ & $(11.55)$ & $(16.63)$ & $(14.53)$ \\
\hline \multirow[t]{2}{*}{ LIQ (-) } & $-0.043 * * *$ & $-0.069 * * *$ & $-0.100 * * *$ & $-0.423 * * *$ & $-0.401 * * *$ & $-0.449 * * *$ \\
\hline & $(-9.24)$ & $(-14.86)$ & $(-20.66)$ & $(-73.91)$ & $(-104.42)$ & $(-76.82)$ \\
\hline \multirow[t]{2}{*}{ RISK $\quad(+)$} & $0.059 * * *$ & $0.026^{* *}$ & 0.003 & $0.025^{* *}$ & 0.005 & $0.010 * * *$ \\
\hline & $(4.52)$ & $(2.19)$ & $(0.26)$ & $(2.61)$ & $(0.72)$ & $(2.73)$ \\
\hline \multirow[t]{2}{*}{ MSHARE1 } & -0.020 & $-0.106 * * *$ & 0.015 & -0.048 & $-0.089 * *$ & 0.013 \\
\hline & $(-1.34)$ & $(-2.91)$ & $(0.97)$ & $(-1.59)$ & $(-1.97)$ & $(0.94)$ \\
\hline Obs. & 31,004 & 31,916 & 32,360 & 25,893 & 25,534 & 26,044 \\
\hline Adjusted $\mathrm{R}^{2}$ & 0.7296 & 0.7001 & 0.6976 & & & \\
\hline Sargan & & & & n.s. & n.s. & n.s. \\
\hline $\mathrm{m} 1$ & & & & $* * *$ & $* * *$ & $* * *$ \\
\hline $\mathrm{m} 2$ & & & & n.s. & n.s. & n.s. \\
\hline
\end{tabular}

This table reports the results for the static (i.e., Fixed effects) as well as the dynamic (i.e., GMM) cash models (White's heteroskedasticity consistent t-statistics in parentheses) tested on subsamples of firms depending on low, medium or high market concentration. The dependent variable in all models is the CASH variable measured as cash and cash equivalents divided by total assets. The first three models are tested using fixed firm and fixed period effects. All explanatory variables are lagged one year to avoid possible endogeneity problems. The three models on the right hand side are tested with GMM, estimated in first differences using the Arellano and Bond (1991) method. The validity of using lagged values of endogenous regressors as instruments was evaluated with the Sargan test of over-identifying restrictions and direct tests of serial correlation in the residuals $\mathrm{m} 1$ and $\mathrm{m} 2$. The Sargan test is $\chi^{2}$ distributed, its significance is reported in the Table. Level of significance: $* * * 1 \% ; * * 5 \% ; * 10 \% ;$ n.s. indicates non significance.

\subsection{Alternative Measures of Market Power}

In order to assess the robustness of our conclusions, we re-estimate our models using either a country based measure of market share, or the price cost margin as an ex post measure of market power. For in the literature on industrial organization market share and price cost margins are both considered to be measures of market power (e.g., Schmalensee, 1989; Hay \& Liu, 1997). Results from these robustness tests can be found in Table 7 (Note 7). 
Table 7. The impact of market power using alternative measures

\begin{tabular}{|c|c|c|c|c|}
\hline \multirow[b]{2}{*}{$\begin{array}{l}\text { Explanatory variables } \\
\text { (expected sign) }\end{array}$} & \multicolumn{2}{|c|}{ Country based market share } & \multicolumn{2}{|c|}{ Excess price cost margin } \\
\hline & Fixed effects & GMM & Fixed effects & GMM \\
\hline Intercept & $\begin{array}{l}0.249 * * * \\
(26.82)\end{array}$ & & $\begin{array}{l}0.242 * * * \\
(25.50)\end{array}$ & \\
\hline $\mathrm{CASH}_{\mathrm{t}-1}$ & & $\begin{array}{l}0.183^{* * *} \\
(17.55)\end{array}$ & & $\begin{array}{l}0.175^{* * *} \\
(17.49)\end{array}$ \\
\hline GROWTH & $\begin{array}{l}0.001 \\
(0.13)\end{array}$ & $\begin{array}{l}0.002 \\
(0.27)\end{array}$ & $\begin{array}{l}-0.002 \\
(-0.28)\end{array}$ & $\begin{array}{l}0.003 \\
(0.77)\end{array}$ \\
\hline SIZE $\quad(-)$ & $\begin{array}{l}-0.012 * * * \\
(-13.41)\end{array}$ & $\begin{array}{l}-0.007 * * * \\
(-6.33)\end{array}$ & $\begin{array}{l}-0.011^{* * *} \\
(-12.87)\end{array}$ & $\begin{array}{l}-0.007^{* * *} \\
(-6.31)\end{array}$ \\
\hline LEV $\quad(+/-)$ & $\begin{array}{l}-0.029 * * * \\
(-10.88)\end{array}$ & $\begin{array}{l}-0.031 * * * \\
(-9.83)\end{array}$ & $\begin{array}{l}-0.031 * * * \\
(-11.09)\end{array}$ & $\begin{array}{l}-0.035^{* * *} \\
(-8.94)\end{array}$ \\
\hline $\mathrm{CF} \quad(+)$ & $\begin{array}{l}0.045 * * * \\
(11.79)\end{array}$ & $\begin{array}{l}0.084 * * * \\
(27.51)\end{array}$ & $\begin{array}{l}0.062 * * * \\
(11.34)\end{array}$ & $\begin{array}{l}0.094 * * * \\
(20.34)\end{array}$ \\
\hline LIQ $\quad(-)$ & $\begin{array}{l}-0.089 * * * \\
(-34.62)\end{array}$ & $\begin{array}{l}-0.419 * * * \\
(-147.42)\end{array}$ & $\begin{array}{l}-0.087 * * * \\
(-33.57)\end{array}$ & $\begin{array}{l}-0.419 * * * \\
(-130.28)\end{array}$ \\
\hline RISK $\quad(+)$ & $\begin{array}{l}0.045^{* * *} \\
(6.10)\end{array}$ & $\begin{array}{l}0.012^{* * *} \\
(4.15)\end{array}$ & $\begin{array}{l}0.043 * * * \\
(5.75)\end{array}$ & $\begin{array}{l}0.010^{* * *} \\
(2.59)\end{array}$ \\
\hline MSHARE & $\begin{array}{l}-0.004 * \\
(-1.76)\end{array}$ & $\begin{array}{l}-0.006^{*} \\
(-1.67)\end{array}$ & & \\
\hline EPCM & & & $\begin{array}{l}-0.017^{* * *} \\
(-3.02)\end{array}$ & $\begin{array}{l}-0.016^{* * *} \\
(-3.31)\end{array}$ \\
\hline Obs. & 99,720 & 79,749 & 98,037 & 78,762 \\
\hline Adjusted $\mathrm{R}^{2}$ & 0.6947 & & 0.6976 & \\
\hline Sargan & & n.s. & & n.s. \\
\hline $\mathrm{m} 1$ & & $* * *$ & & $* * *$ \\
\hline $\mathrm{m} 2$ & & n.s. & & n.s. \\
\hline
\end{tabular}

This table reports the results for the static (i.e., Fixed effects) as well as the dynamic (i.e., GMM) cash models (White's heteroskedasticity consistent $\mathrm{t}$-statistics in parentheses). The dependent variable in all models is the CASH variable measured as cash and cash equivalents divided by total assets. Models (1) and (3) are tested using fixed firm and fixed period effects. All explanatory variables are lagged one year to avoid possible endogeneity problems. Models (2) and (4) are tested with GMM, estimated in first differences using the Arellano and Bond (1991) method. The validity of using lagged values of endogenous regressors as instruments was evaluated with the Sargan test of over-identifying restrictions and direct tests of serial correlation in the residuals $\mathrm{m} 1$ and $\mathrm{m} 2$. The Sargan test is $\chi^{2}$ distributed, its significance is reported in the Table. Level of significance: *** $1 \% ; * * 5 \% ; * 10 \%$; n.s. indicates non significance.

In defining the main proxy for market share, we assumed that the every European firm in our sample competes in the same European wide product market. Although this may be accurate for most firms, some firms may compete on a smaller scale. Therefore, as an alternative measure for market share, we recalculate the market share variable based on country specific product markets only. Using the 3-digit industry SIC codes as industry classification, the market share of a firm is then measured by dividing the sales in a certain year by the total sales in the corresponding home country industry. Evidently, market shares become somewhat larger on average. The first two models in Table 7 show the results for the country based market share in the static and dynamic setting respectively. The coefficient estimate for the alternative market share variable is negative and significant which confirms that our main conclusions about the influence of market share on cash policy are robust to different specifications of market share.

Finally, we test whether other proxies for market power, like the price cost margin, have a similar relationship with cash policy. In contrast to market share, price cost margin is a more ex post measure of market power. As in Drakos and Goulas (2006), we define the price cost margin (PCM) as operating income (before depreciation) over sales. The excess price cost margin (EPCM) is then calculated as the difference between the firm specific PCM and the industry median based on the 3-digit SIC code industry classification. We use EPCM rather than PCM in order to control for industry specific effects. Firms that are able to exceed their industry in terms of PCM have higher market power. Table 7 shows that consistent with our main conclusions on market share, the 
excess price cost margin also has a negative and significant impact on cash holdings. This confirms the main hypothesis that firms with higher market power worry less about predation risk and are therefore able to lower the precautionary cash buffer. Other determinants of cash holdings are not qualitatively altered by this replacement of market share with the excess price cost margin in the static as well as the dynamic cash model.

\section{Concluding Remarks}

Using a large sample of consolidated statements from European companies in 14 countries, we examine the impact of market share on cash policy. Our key conclusions are that a firm is more likely to hold cash reserves when its market share is low and that this relation between market share and cash holdings is most important when the risk of predation is high. This confirms our main hypothesis that firms with high market shares are expected to worry less about predation risk resulting in lower precautionary cash buffers.

Our results hold in static as well as dynamic cash models and are robust to different specifications of market share, predation risk, and for controlling for possible endogeneity. These findings show that one of the advantages of maintaining a sufficiently important market share in a competitive environment is that it adds to the efficiency of the use of assets as less cash reserves are needed. In this way it offers another motive to explain the observed phenomenon that many firms consider market share to be important, strive to increase it or at least take action to maintain their position in their industry.

\section{References}

Almeida, H., Campello, M., \& Weisbach, M. S. (2004). The cash flow sensitivity of cash. Journal of Finance, 59, 1777-1804. http://dx.doi.org/10.1111/j.1540-6261.2004.00679.x

Acharya, V. V., Almeida, H., \& Campello, M. (2007). Is cash negative debt? A hedging perspective on corporate financial policies. Journal of Financial Intermediation, 16, 515-554. http://dx.doi.org/10.1016/j.jfi.2007.04.001

Akdogu, E., \& MacKay, P. (2008). Investment and competition. Journal of Financial and Quantitative Analysis, 43, 299-330. http://dx.doi.org/10.1017/S0022109000003537

Arellano, M., \& Bond, S. R. (1991). Some tests of specification for panel data: Monte Carlo evidence and an application to employment equations. The Review of Economic Studies, 58, 277-297. http://dx.doi.org/10.2307/2297968

Bates, T. W., Kahle, K. M., \& Stulz, R. M. (2009). Why do U.S. firms hold so much more cash than they used to? Journal of Finance, 64, 1985-2021. http://dx.doi.org/10.1111/j.1540-6261.2009.01492.x

Baumol, W. J. (1952). The transactions demand for money: an inventory theoretic approach. Quarterly Journal of Economics, 66, 545-556. http://dx.doi.org/10.2307/1882104

Bolton, P., \& Scharfstein, D. S. (1990). A theory of predation based on agency problems in financial contracting. American Economic Review, 80, 93-106.

Campello, M. (2006). Debt financing: Does it boost or hurt firm performance in product markets? Journal of Financial Economics, 82, 135-172. http://dx.doi.org/10.1016/j.jfineco.2005.04.001

Claessens, S., \& Tzioumis, K. (2006). Ownership and financing structures of listed and large non-listed corporations. Corporate Governance, 14, 266-276. http://dx.doi.org/10.1111/j.1467-8683.2006.00506.x

Demsetz, H. (1974). Two systems of belief about monopoly. In ed H.J. Goldschmid, H.M. Mann and J.F. Weston, Industrial Concentration: The new learning. Boston, MA: Little Brown.

Dew-Becker, I., \& Gordon, R. J. (2008). The role of labour market changes in the slowdown of European productivity growth. Working paper, NBER No. 13840.

Dittmar, A., \& Mahrt-Smith, J. (2007). Corporate governance and the value of cash holdings. Journal of Financial Economics, 83, 599-634. http://dx.doi.org/10.1016/j.jfineco.2005.12.006

Dittmar, A., Mahrt-Smith, J., \& Servaes, H. (2003). International corporate governance and corporate cash holdings. Journal of Financial and Quantitative Analysis, 38, 111-133. http://dx.doi.org/10.2307/4126766

Drakos, K., \& Goulas, E. (2006). Investment and conditional uncertainty: the role of market power, $\begin{array}{llll}\text { irreversibility, and returns-to-scale. Economic Letters, } & \text { 93, 169-175. }\end{array}$ http://dx.doi.org/10.1016/j.econlet.2006.04.007

Ferreira, M. A., \& Vilela, A. (2004). Why do firms hold cash? Evidence from EMU countries. European Finance Management, 10, 295-319. http://dx.doi.org/10.1111/j.1354-7798.2004.00251.x 
Frésard, L. (2010). Financial strength and product market behavior: the real effects of corporate cash holdings. Journal of Finance, 65, 1097-1122. http://dx.doi.org/10.1111/j.1540-6261.2010.01562.x

Froot, K. A., Scharfstein, D. S., \& Stein, J. C. (1993). Risk management: coordinating corporate investment and financing policies. Journal of Finance, 48, 1629-1658.

Garcia-Teruel, P. J., \& Martinez-Solano, P. (2008). On the determinants of SME cash holdings: Evidence from

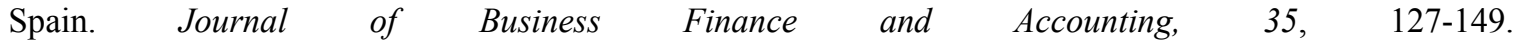
http://dx.doi.org/10.1111/j.1468-5957.2007.02022.x

Gaspar, J., \& Massa, M. (2006). Idiosyncratic volatility and product market competition. Journal of Business, 79 , 3125-3152. http://dx.doi.org/10.1086/505251

Han, S., \& Qiu, J. (2007). Corporate precautionary cash holdings. Journal of Corporate Finance, 13, 43-57. http://dx.doi.org/10.1016/j.jcorpfin.2006.05.002

Haushalter, D., Klasa, S., \& Maxwell, W. F. (2007). The influence of product market dynamics on the firm's cash holdings and hedging behavior. Journal of Financial Economics, 84, 797-825. http://dx.doi.org/10.1016/j.jfineco.2006.05.007

Hay D., \& Liu, G. (1997). The efficiency of firms: what difference does competition make? The Economic Journal, 107, 597-617. http://dx.doi.org/10.1111/j.1468-0297.1997.tb00029.x

Hou, K., \& Robinson, D. T. (2006). Industry concentration and average stock returns. Journal of Finance, 61, 1927-1956. http://dx.doi.org/10.1111/j.1540-6261.2006.00893.x

Jensen, M. C. (1986). Agency cost of free cash flow, corporate finance, and takeovers. American Economic Review, 76, 323-329.

Kovenock, D., \& Phillips, G. (1997). Capital structure and product market behavior: an examination of plant exit and investment decisions. Review of Financial Studies, 10, 767-803. http://dx.doi.org/10.1093/rfs/10.3.767

MacKay, P., \& Phillips, G. (2005). How does industry affect firm financial structure? Review of Financial Studies, 18, 1433-1466. http://dx.doi.org/10.1093/rfs/hhi032

Mikkelson, W. H., \& Partch, M. M. (2003). Do persistent large cash reserves hinder performance? Journal of Financial and Quantitiative Analysis, 38, 275-294. http://dx.doi.org/10.2307/4126751

Morellec, E., \& Nikolov, B. (2008). Cash holdings and competition. Working paper, Ecole Polytechnique Fédéral de Lausanne.

Myers, S., \& Majluf, N. (1984). Corporate financing and investment decisions when firms have information that investors do not have. Journal of Financial Economics, 13, 187-221. http://dx.doi.org/10.1016/0304-405X(84)90023-0

Opler, T., Pinkowitz, L., Stulz, R., \& Williamson, R. (1999). The determinants and implications of corporate cash holdings. Journal of Financial Economics, 52, 3-46. http://dx.doi.org/10.1016/S0304-405X(99)00003-3

Ozkan, A., \& Ozkan, N. (2004). Corporate cash holdings: An empirical investigation of UK companies. Journal of Banking and Finance, 28, 2103-2134. http://dx.doi.org/10.1016/j.jbankfin.2003.08.003

Pal, R., \& Ferrando, A. (2010). Financing constraints and firms' cash policy in the euro area. The European Journal of Finance, 16, 153-171. http://dx.doi.org/10.1080/13518470903075748

Pinkowitz, L., Stulz, R., \& Williamson, R. (2006). Does the contribution of corporate cash holdings and dividends to firm value depend on governance? A cross-country analysis. Journal of Finance, 61, 2725-2751. http://dx.doi.org/10.1111/j.1540-6261.2006.01003.x

Riddick, L., \& Whited, T. (2009). The corporate propensity to save. Journal of Finance, 64, 1729-1766. http://dx.doi.org/10.1111/j.1540-6261.2009.01478.x

Schmalensee, R. (1989). Inter-Industry Studies of Structure and Performance. In Handbook of Industrial Organization, eds. R. Schmalensee and R.D. Willig. North-Holland: Elsevier. http://dx.doi.org/10.1016/S1573-448X(89)02004-2

Zingales, L. (1998). Survival of the fittest or the fattest? Exit and financing in the trucking industry. Journal of Finance, 53, 905-938. http://dx.doi.org/10.1111/0022-1082.00039

\section{Notes}

Note 1. In the US such calculation is only possible for years for which Census data are available. However, including non listed firms is important for the accuracy of the calculated competition measures (e.g., Haushalter 
et al., 2007). In Europe this seems to be especially important as $90 \%$ of the large firms in our sample are not listed. This latter finding is comparable to Claessens and Tzioumis (2006) who construct a database of all large firms of 19 European countries. They report that about $87 \%$ of these companies are unlisted.

Note 2. As an alternative measure of cash holdings we subtract cash and marketable securities from total assets in the denominator which gives us cash levels scaled by net assets (Opler et al., 1999). Results remain qualitatively similar if this alternative measure of cash holdings is used.

Note 3. Gaspar and Massa (2006) show that market share has an influence on idiosyncratic volatility, which indicates that market share could influence income risk as well. Although in our sample market share and risk are negatively correlated (about 3\%), the correlation seems too small to cause any problems. As a robustness check however we re-estimated our cash models without the risk variable. Results remain qualitatively the same.

Note 4. Different definitions of growth opportunities like firms specific sales growth or other industry classifications yield the same result.

Note 5. Haushalter et al. (2007) incorporate their similarity measure as a continuous variable in the cash model. In a (not reported) robustness test, we also find a significantly negative coefficient for the continuous similarity variable in our static and dynamic cash models.

Note 6. Our results are qualitatively similar if we use alternative percentile cutoffs in market concentration to subdivide the sample in three groups.

Note 7. To limit the number of Tables we report only the tests for our main hypothesis, i.e. hypothesis 1 . The results for the other hypothesis remain qualitatively similar to those reported in Table 4 and 5, i.e. also for the other measures of market share discussed below and for the price cost margin it remains the case that when predation risk is high, market share or the price cost margin has a significant effect upon cash holdings, while this is not the case when predation risk is low. These findings can be obtained upon request. 